REVIEWS

\title{
Folded genome as a platform for the functional compartmentalization of the eukaryotic cell nucleus
}

\author{
E. S. Ioudinkova ${ }^{1,2}$, A. A. Gavrilov ${ }^{1,2}$, S. V. $\operatorname{Razin}^{1,2,3}$ \\ ${ }^{1}$ Institute of Gene Biology, Russian Academy of Sciences \\ 34/5, Vavilova Str., Moscow, Russian Federation, 119334 \\ ${ }^{2}$ LIA 1066 French-Russian Joint Cancer Research Laboratory \\ Villejuif, France-Moscow, Russian Federation \\ ${ }^{3}$ Department of Molecular Biology, Faculty of Biology, M. V. Lomonosov Moscow State University \\ Leninskie gory, Moscow, Russian Federation, 119992 \\ ioudinkova@inbox.ru
}

\begin{abstract}
In a number of recent studies a tight interconnection between the spatial organization of the eukaryotic genome and its functioning has been demonstrated. Moreover, it is becoming evident that the folded DNA by itself constitutes an important, if not the key, factor supporting the internal nuclear organization. In this review, we will discuss the current state of chromatin research with the special attention focused on chromosome territories, chromatin folding and dynamics, chromatin domains, transcription and replication factories. Based on this analysis we will show how interphase chromosomes define the assembly of different nuclear compartments and underlie the spatial compartmentalization of the cell nucleus.
\end{abstract}

Keywords: chromosome folding, nuclear compartments, genome spatial organization.

Introduction. For many years, the eukaryotic cell nucleus was considered as a test tube where different processes related to the genome activity were proceeding in solution. Now it is clear that this point of view is very far from reality. It has been demonstrated that the nucleus is subdivided into a number of functional compartments adapted to perform various functional processes [1-4]. The list of characterized nuclear compartments includes replication and transcription factories, splicing speckles, Cajal bodies, PML bodies, polycomb bodies and is constantly expanding. As a matter of fact, staining the nuclei with antibodies raised against a number of different proteins reveals some kind of foci, which argues for the existence of numerous functional compartments within the cell nucleus. Taking into account all these observations one may pose a question as to what constitutes a structural basis for the assembly of various nuclear compartments. It has been proposed that all functional compart-

(C) Institute of Molecular Biology and Genetics, NAS of Ukraine, 2014 ments are assembled on the nuclear matrix [5, 6]. Indeed, replication and transcription foci as well as other nuclear compartments could be observed on isolated nuclear matrices after removal of a bulk of chromatin [6-9].

However, the nature of the nuclear matrix itself remains unclear. Numerous attempts to identify and characterize a proteinous network within the cell nucleus (i. e. something similar to the cytoskeleton) resulted in controversial observations and conclusions [10-12]. Presently, most of the scientists agree that the so-called internal nuclear matrix does not exist in living cell (for a review see $[9,13])$.

The nuclear lamina appears to be the only skeletal element of the cell nucleus. However, most of the functional compartments are located far from the nuclear lamina inside nucleus. Thus, nuclear lamina cannot, at least directly, support positioning of nuclear compartments. Here we propose that folded DNA itself fulfills the scaffolding function for the nuclear compartments. 
Spatial organization of interphase chromosomes. Chromosomes become visible in mitosis. However, the fate of chromosomes in interphase remained enigmatic until chromosome-specific probes and confocal microscopy were developed. Using FISH with chromosome-specific probes followed by the analysis under confocal microscope, Cremer and collaborators demonstrated that, in interphase, individual chromosomes occupy relatively compact non-overlapping regions that were named «chromosomal territories» $[14,15]$. Chromosomal territories appeared to be separated by some space that was relatively free of chromatin. This space was termed «InterChromatin Domain», ICD, and was proposed to serve for the transport of different compounds across nuclei [14]. Later it was found that the interchromatin domain spanned also chromosomal territories so that internal regions were also easily accessible for different compounds including enzymes involved in DNA and RNA metabolism $[3,15,16]$. The interchromatin domain also allows fast transport of RNA (RNP particles) from transcription factories to the nuclear periphery and finally to the cytoplasm [17]. High-resolution microscopic analysis performed using combined chromatin staining and immunostaining of different nuclear compartments demonstrated that splicing speckles, PML bodies and several other functional compartments are situated in the interchromatin domain [18]. It will thus be correct to say that the specificity of interphase chromosome folding delimits the portion of the nuclear space that can be used for the assembly of the above-mentioned compartments. It should be noted that chromosome territories are not randomly positioned within the nucleus. It has been mentioned that homologous chromosomes are positioned far from each other. Gene-dense chromosomes tend to be located in the central part of the nucleus and gene-poor chromosomes tend to the nuclear periphery [14, 19-22]. If chromosome possesses generich and gene-poor regions, it acquires such a configuration that gene-rich regions are located closer to the nuclear center and gene-poor regions - closer to the nuclear periphery [23]. One particular example is a centromeric region that is gene-poor and is located in the part of the chromosomal territory that is closer to the nuclear periphery [24]. The modern model of the interphase chromosome organization is based on the results obtained using the so-called $\mathrm{C}$-methods $[25,26]$. Of particular importance are the data obtained using the $\mathrm{Hi}-\mathrm{C}$ protocol which permits to study general principles of chromatin folding in interphase chromosomes [27]. Hi-C analysis has demonstrated that chromosomes are partitioned into topologically-associated domains (TADs) of various sizes (from several hundred $\mathrm{Kb}$ to several $\mathrm{Mb}$ ) [28-30]. This organization is characterized by high frequency of intra-TAD contacts of remote genomic elements and low frequency of inter-TAD contacts of remote genomic elements. Modelling experiments suggest that a TAD can be considered as a globule. However, the path of the chromatin fiber within the globule is not clear. There are some data in favor of the fractal globule and some data in favor of the molten globule [31, 32]. The situation is complicated by the fact that the actual mode of chromatin packaging within the cell nucleus is likely to differ drastically from the one predicted based on in vitro experiments. For years, it has been generally accepted that chromatin is organized in a more or less regular hierarchical set of folded structures starting from the $10 \mathrm{~nm}$ fiber («beads on the string») that is further packed in the $30 \mathrm{~nm}$ fiber arranged in $\sim 100 \mathrm{~Kb}$ looped domains [33, 34]. Recent studies performed using electron cryotomography, and electron spectroscopic imaging (ESI) combined with electron tomography provided no evidence for the existence of the $30 \mathrm{~nm}$ fibers within the non-disturbed cell nucleus [35-37]. Both euchromatic and heterochromatic regions appeared to be composed of tightly packed $10 \mathrm{~nm}$ fibers [36]. This less regular organization should allow more flexible positioning of nucleosomes and nucleosomal fibers suggesting there is a way to suppress interactions between neighboring fibers. Here the modification of histones and the removal of architectural proteins may play an essential role. Based on the hierarchical model of chromatin folding, it was reasonable to assume that progressive expansion of chromatin domains occurs along the chromatin chain. Within a globule composed of irregularly (stochastically) folded and closely spaced $10 \mathrm{~nm}$ chromatin fibers, the distances between nucleosomes located on the same and neighboring $10 \mathrm{~nm}$ fibers are likely to be comparable if not the same [35-37]. Correspondingly, the expansion of a chromatin domain mediated by the progressive modification of histones is to be considered as a process that occurs in all possible directions within the 3D nuclear space. Consequently, a three-dimensional, at first appro- 
ximation, globular chromatin domain will be formed. This domain may be mosaic $i$. e. be composed of segments of chromosomes that do not necessarily neighbor each other on a linear DNA chain. In case of spreading active signals, the loosely packed and thus expanded 3D domain will easily accommodate a transcription factory or other functional compartments (reconfiguration of chromatin occurs also in connection with DNA repair).

It is necessary to underline that all the above-mentioned organization is highly dynamic. The local mobility (range of fluctuations) of nucleosomes in nuclear chromatin was estimated experimentally and found to constitute $\sim 50 \mathrm{~nm} / 30 \mathrm{~ms}$ [38]. Higher-order organization of chromosomes is also dynamic as it shows cell to cell variations. Although $\mathrm{C}$-methods give an integral picture based on a statistical analysis, FISH data clearly demonstrate that the mutual positions of different genomic regions in individual cells present in a population are variable [39-41].

The same applies to the mutual positions of chromosomal territories $[15,24,42]$. Furthermore, it was demonstrated that in living cells chromosomal territories constantly move $[43,44]$.

The nature of nuclear compartments and the role of folded chromosomes in their positioning. The term «nuclear compartment» is not well defined. One can consider euchromatin and heterochromatin as functional compartments. Respectively, perilamellar, perinucleolar and pericentromeric regions should be considered as special compartments because heterochromatin is located preferentially in these areas. It is hardly necessary to prove that the folded genome plays an essential, if not crucial, role in the organization of these compartments. Indeed, it has been shown that the localization of chromosomal regions in respect to the nuclear lamina is nonrandom. Segments of the interphase chromosomes that are located in vicinity of the nuclear lamina and nucleolus (Lamina Associated Domains LADs [45, 46] and Nucleollar Associated Domains, NADs [47]) have been identified and characterized. Genomic data demonstrate that LADs and NADs significantly overlap. It looks likely that in each cell the pattern of association of inactive chromatin regions with either the nuclear lamina or nucleolus is established de novo after mitosis and that the partitioning of inactive genomic domains between the perinuclear (perilamellar) and perinucleolar layers occurs at random $[32,47]$. Based on these observations one may suggest that the assembly of inactive domains is controlled by the internal signals (ex.: profiles of histone modifications) and their positioning in the vicinity of either nuclear lamina or nucleolus occurs in a passive fashion in order to make room for the proper spatial organization of active chromosomal segments. This point of view does not contradict the observations demonstrating that the forced repositioning of a gene to the nuclear periphery causes inactivation of this gene [48-51]. This is due to the presence of heterochromatin in this region rather than the direct interaction with the nuclear lamina. All chromatin compartments are highly dynamic. Heterochromatin is constantly disassembled and assembled. Indeed, the exchange rate of structural components of heterochromatin (HP1 and PcG proteins) constitutes just seconds $[52,53]$. The equilibrium is, however, moved in the direction of heterochromatin assembly due to the high local concentration of histone deacetylases and other proteins involved in the heterochromatin assembly. These enzymes will be attracted to the area just by the high concentration of nucleosomes bearing relatively stable histone modifications typical of heterochromatin (ex.: H3K9-trimet). It is not surprising that any chromatin fragment placed in such a locality will become heterochromatic. The conversion of euchromatin to heterochromatin in this case will simply follow the principle of spatial expansion of a heterochromatin domain explained in the previous section.

The most important functional compartments of the genome are transcription and replication factories [54$56]$ as they are directly involved in the transfer of genetic information. Replication factories were first observed as replication foci, focal places where DNA synthesis occurred as followed from the analysis of spatial distribution of the places of BUdR incorporation into nascent DNA [57]. It was then shown that the same foci could be visualized in G1 cells by immunostaining with antibodies against replication factor A [58]. Although this observation may be interpreted in terms of the model postulating that replication factories are special assemblies of replication enzymes that exist in the absence of replication, the simplest explanation is that the replication machinery is assembled at replication origins before the onset of replication. Several replication origins are likely to be located close to each other in the nuclear 
space. Upon simultaneous activation of these replication origins replication factories containing several replication forks located in close spatial proximity will be formed. Although it has been proposed that mutual positions of replication origins are locked by special links (for example, by association with the nuclear matrix [6, 59]) there are not much data supporting this model. We think that the location of several replication origins in spatial proximity may be provided just by the way of chromatin fiber folding. With the assembly of replication forks, the protein complexes attached to DNA become large enough to be gathered together and held in a complex (replication factory) by the depletion attraction force [60-62]. Different procedures used for the nuclear matrix isolation are likely to stabilize these dynamic assemblies so that they can be observed in chromatin-depleted nuclei [63]. The relation of replication clusters to TADs is not clear at the moment. Based on the sizes of replicons $(\sim 100 \mathrm{~kb}$ on the average $[64,65])$ one may speculate that TADs correspond to replicon clusters identified by immunostaining [66]. Under certain conditions, these clusters can be unfolded into a rosette-like structure.

Transcription factories have gained much attention in resent researches [54, 55, 67]. It has been proposed that they exist in the absence of transcription [68] and that to be transcribed genes should be moved to the preexisting transcription factories $[54,55]$. This may indeed happen in the case of activation of tissue-specific gene transcription which is likely to occur at preexisting transcription factories mediating transcription of house-keeping genes.

However, there is no solid evidence for the existence of transcription factories in the absence of transcription. The conditions used to study this question ensured transcription arrest but not disassembly of elongating Pol II complexes [68]. The force that could bring inactive gene to a transcription factory remains enigmatic. We have proposed that the Pol II pre-initiation complex is assembled on a gene located at a distance from the transcription factory [67]. Later this gene can be brought to the transcription factory by the depletion attraction force $[69,70]$. The same force may bring together several genes with assembled Pol II pre-initiation complexes. In this way a new transcription factory will be formed $[67,71]$. Recent analysis of the mobility of Pol
II in living cells strongly supports the model of dynamic transcription factories [72]. If indeed assembly of Pol II complexes into factories is mediated by the depletion attraction mechanism, the main factor determining the specificity of gene association in transcription factories should be their spatial proximity. Although it was reported that in erythroid cells there is a preference of assembly of erythroid-specific genes into common transcription factories [39], the presented data did not strongly support this conclusion. Indeed, although the probability to find two erythroid-specific genes in the same transcription factory was a little higher than expected based on the occasional distribution of transcribed genes between all transcription factories, the probability that three or more erythroid-specific genes shared the same transcription factory was already less than expected based on the random distribution [39].

Other data including our own observations made in the chicken erythroid cells (unpublished) strongly support the supposition that genes located close to each other (at least within the same TAD) tend to share transcription factories. Of course, there are well documented cases when genes from different chromosomal territories share the same transcription factory, for example IgH and c-myc in B cells [40]. Apparently, this is due to some peculiarities in the folding of chromatin in both territories.

In most eukaryotic cells, there are two types of chromatin domains - Constitutive (mostly centromeric) heterochromatin organized via H3K9 tri-methylation and recruitment of HP1 $[73,74]$ and facultative heterochromatin organized via $\mathrm{H} 3 \mathrm{~K} 27$ tri-methylation and recruitment of Polycomb group proteins (PcG) [75]. Genomic regions repressed via recruitment of $\mathrm{PcG}$ tend to associate to form the so-called Polycomb bodies (PC bodies). This process is best studied in Drosophila cells. Assembly of PcG targets into repressive chromatin compartments appears to enhance the level of the PcG-mediated transcriptional silencing [76], apparently due to the increase of repressive factor local concentration. The integrity of the repressive compartment is likely supported by the interactions between insulator proteins. Whatever is the precise mechanism of the PC body formation, it is clear that repression by $\mathrm{PcG}$ proteins involve reconfiguration of chromatin in a relatively large genomic area(s). 
Summarizing one may conclude that many nuclear compartments are assembled starting from nucleation centers located on a chromatin fiber. The positioning of these compartments is mediated by folding the chromatin fibers. Other compartments (such as splicing speckles) are located in interchromatin domain. Already for this reason the way of chromatin folding will partially determine their positions. However, it is possible that these compartments are indirectly linked to some particular genomic regions. Indeed, it has been demonstrated that, at least in some cases, active genes (and thus, transcription factories) are located at the surface of the speckles [77], and transcribed RNA is moved to the speckles [78, 79]. The mechanism of the speckle assembly is not clear at the moment. Some authors consider speckles as places where non-used components of the splicing machinery are temporarily deposited. Others suggest that splicing occurs within speckles. If the latter is true, the speckles may expand and collapse depending on functional necessity. Obviously, their positions in this case will be determined by positions of active genomic regions.

Conclusions. For many years the spatial organization of interphase chromosomes and functional compartmentalization of the eukaryotic cell nucleus have been studied independently. Now it is becoming increasingly evident that they are tightly interconnected. It is likely that folded chromosomes underlie the spatial compartmentalization of the eukaryotic cell nucleus constituting a structural milieu for the assembly of functional compartments. One thing that should be stresses is that both the chromosome folding and functional compartmentalization of the cell nucleus are highly dynamic. Chromosomes can adopt numerous alternative configurations as follows from FISH data [39-41], and nuclear compartments are constantly assembled and disassembled as follows from the high exchange rates of their constituents [80]. The equilibrium between all these processes can be modulated by a number of factors. Apparent order in the eukaryotic cell nucleus is in a way illusive. It originates from disorder via continuous choices between different spatial arrangements aimed to adapt the functioning of the genome to the current conditions.

Funding. This work was supported by Presidium of the Russian Academy of Sciences (grant MCB) and by RFBR grants 12-04-93109, 12-04-93110, 12-0400313-a, 13-04-93105-a and 14-04-00010.
Упакований геном як основа функціональної

компартменталізації ядра евкаріотичної клітини

Є. С. Юдинкова, А. А. Гаврилов, С. В. Разин

\section{Резюме}

У низиі недавніх робіт продемонстровано тісний взаємозв'язок між просторовою організацією евкаріотичного геному $i$ його функціонуванням. Більш того, стає очевидним, щчо упакована ДНК сама по собі є важливим, якщо не ключовим, фактором, котрий підтримує внутрішню організацію ядра. В огляді ми обговорюємо існуючий стан досліджень у галузі хроматину, акцентуючи увагу на питаннях, пов'язаних з хромосомними територіями, фолдингом і динамікою хроматину, а також хроматиновим доменам, транскрипиійним і реплікачійним фабрикам. На основі иього ми показуємо, що інтерфазні хромосоми визначають збирання різних ядерних компартментів і створюють підгрунтя для просторової компартменталізацї клітинного ядра.

Ключові слова: фолдинг хромосом, ядерні компартменти, просторова організація геному.

Упакованный геном как основа функциональной компартментализации ядра эукариотической клетки

Е. С. Юдинкова, А. А. Гаврилов, С. В. Разин

Резюме

В ряде недавних работ продемонстрирована тесная взаимосвязь между пространственной организацией эукариотического генома и его функиионированием. Более того, становится очевидным, что упакованная ДНК сама по себе является важным, если не ключевым, фактором, поддерживаюшим внутреннюю организацию ядра. В обзоре мы обсуждаем текущее состояние исследований в области хроматина, особое внимание уделяя вопросам, связанным с хромосомными территориями, фолдингом и динамикой хроматина, а также хроматиновым доменам, транскрипчионнылм и репликационным фабрикам. На основе этого мы показываем, что интерфазные хромосомы определяют сборку различных ядерных компартментов и создают основу для пространственной компартментализации клеточного ядра.

Ключевые слова: фолдинг хромосом, ядерные компартменmbl, пространственная организация генома.

\section{REFERENCES}

1. Misteli T. Cell biology of transcription and pre-mRNA splicing: nuclear architecture meets nuclear function. J Cell Sci. 2000; 113(Pt 11):1841-9.

2. Dundr M, Misteli T. Functional architecture in the cell nucleus. Biochem J. 2001; 356(Pt 2):297-310.

3. Geyer PK, Vitalini $M W$, Wallrath LL. Nuclear organization: taking a position on gene expression. Curr Opin Cell Biol. 2011; 23(3):354-9.

4. Matera AG, Izaguire-Sierra M, Praveen $K$, Rajendra TK. Nuclear bodies: random aggregates of sticky proteins or crucibles of macromolecular assembly? Dev Cell. 2009; 17(5):639-47.

5. Shaper JH, Pardoll DM, Kaufmann SH, Barrack ER, Vogelstein $B$, Coffey DS. The relationship of the nuclear matrix to cel- 
lular structure and function. Adv Enzyme Regul. 1978; 17: 213-48.

6. Berezney R, Mortillaro MJ, Ma H, Wei X, Samarabandu J. The nuclear matrix: a structural milieu for genomic function. Int Rev Cytol. 1995; 162A:1-65.

7. Xing YG, Lawrence JB. Preservation of specific RNA distribution within the chromatin-depleted nuclear substructure demonstrated by in situ hybridization coupled with biochemical fractionation. J Cell Biol. 1991; 112(6):1055-63.

8. Stein GS, van Wijnen AJ, Stein JL, Lian JB, Pockwinse S, McNeil $S$. Interrelationships of nuclear structure and transcriptional control: functional consequences of being in the right place at the right time. J Cell Biochem. 1998; 70(2):200-12.

9. Hancock R. Internal organisation of the nucleus: assembly of compartments by macromolecular crowding and the nuclear matrix model. Biol Cell. 2004; 96(8):595-601.

10. Jack RS, Eggert H. The elusive nuclear matrix. Eur J Biochem. 1992; 209(2):503-9.

11. Nickerson J. Experimental observations of a nuclear matrix. J Cell Sci. 2001; 114(Pt 3):463-74.

12. Simon $D N$, Wilson $K L$. The nucleoskeleton as a genome-associated dynamic «network of networks». Nat Rev Mol Cell Biol. 2011; 12(11):695-708.

13. Hancock R. A new look at the nuclear matrix. Chromosoma. 2000; 109(4):219-25.

14. Cremer T, Cremer C. Chromosome territories, nuclear architecture and gene regulation in mammalian cells. Nat Rev Genet. 2001; 2(4):292-301.

15. Cremer T, Cremer M. Chromosome territories. Cold Spring Harb Perspect Biol. 2010; 2(3):a003889.

16. Cremer T, Cremer M, Dietzel S, Muller S, Solovei I, Fakan S. Chromosome territories - a functional nuclear landscape. Curr Opin Cell Biol. 2006; 18(3):307-16.

17. Markaki Y, Gunkel M, Schermelleh L, Beichmanis S, Neumann J, Heidemann M, Leonhardt H, Eick D, Cremer C, Cremer T. Functional nuclear organization of transcription and DNA replication: a topographical marriage between chromatin domains and the interchromatin compartment. Cold Spring Harb Symp Quant Biol. $2010 ; 75: 475-92$.

18. Cremer T, Kupper K, Dietzel S, Fakan S. Higher order chromatin architecture in the cell nucleus: on the way from structure to function. Biol Cell. 2004; 96(8):555-67.

19. Habermann FA, Cremer M, Walter J, Kreth G, von Hase J, Bauer $K$, Wienberg J, Cremer C, Cremer T, Solovei I. Arrangements of macro- and microchromosomes in chicken cells. Chromosome Res. 2001; 9(7):569-84.

20. Croft JA, Bridger JM, Boyle S, Perry P, Teague P, Bickmore WA. Differences in the localization and morphology of chromosomes in the human nucleus. $J$ Cell Biol. 1999; 145(6):1119-31.

21. Boyle S, Gilchrist S, Bridger JM, Mahy NL, Ellis JA, Bickmore $W A$. The spatial organization of human chromosomes within the nuclei of normal and emerin-mutant cells. Human Mol Genet. 2001; 10(3):211-9.

22. Mayer R, Brero A, von Hase J, Schroeder T, Cremer T, Dietzel S. Common themes and cell type specific variations of higher order chromatin arrangements in the mouse. BMC Cell Biol. 2005; 6:44.

23. Lukasova E, Kozubek S, Kozubek M, Falk M, Amrichova J. The 3D structure of human chromosomes in cell nuclei. Chromosome Res. 2002; 10(7):535-48.
24. Taslerova R, Kozubek S, Lukasova E, Jirsova P, Bartova E, Kozubek $M$. Arrangement of chromosome 11 and 22 territories, EWSR 1 and FLII genes, and other genetic elements of these chromosomes in human lymphocytes and Ewing sarcoma cells. Hum Genet. 2003; 112(2):143-55.

25. de Wit $E$, de Laat $W$. A decade of $3 C$ technologies: insights into nuclear organization. Genes Dev. 2011; 26(1):11-24.

26. Gavrilov AA, Razin SV, Iarovaia OV. C-methods to study 3D organization of the eukaryotic genome. Biopolym Cell. 2012; 28 (4):245-51.

27. Belton JM, McCord RP, Gibcus JH, Naumova N, Zhan Y, Dekker $J$. Hi-C: a comprehensive technique to capture the conformation of genomes. Methods. 2012; 58(3):268-76.

28. Lieberman-Aiden E, van Berkum NL, Williams L, Imakaev $M$, Ragoczy T, Telling A, Amit I, Lajoie BR, Sabo PJ, Dorschner MO, Sandstrom R, Bernstein B, Bender MA, Groudine M, Gnirke A, Stamatoyannopoulos J, Mirny LA, Lander ES, Dekker J. Comprehensive mapping of long-range interactions reveals folding principles of the human genome. Science. 2009; 326(5950):289-93.

29. Dixon JR, Selvaraj S, Yue F, Kim A, Li Y, Shen Y, Hu M, Liu JS, Ren $B$. Topological domains in mammalian genomes identified by analysis of chromatin interactions. Nature. 2012; 485(7398): 376-80.

30. Sexton T, Yaffe E, Kenigsberg E, Bantignies F, Leblanc B, Hoichman M, Parrinello H, Tanay A, Cavalli $G$. Three-dimensional folding and functional organization principles of the Drosophila genome. Cell. 2012; 148(3):458-72.

31. Mirny LA. The fractal globule as a model of chromatin architecture in the cell. Chromosome Res. 2011; 19(1):37-51.

32. Bickmore WA, van Steensel B. Genome architecture: domain organization of interphase chromosomes. Cell. 2013; 152(6): 1270-84.

33. Olins $D E$, Olins $A L$. Chromatin history: our view from the bridge. Nat Rev Mol Cell Biol. 2003; 4(10):809-14.

34. Getzenberg RH, Pienta KJ, Ward WS, Coffey DS. Nuclear structure and the three-dimensional organization of DNA.J Cell Biochem. 1991; 47(4):289-99.

35. Gan L, Ladinsky MS, Jensen GJ. Chromatin in a marine picoeukaryote is a disordered assemblage of nucleosomes. Chromosoma. 2013; 122(5):377-86.

36. Fussner E, Strauss M, Djuric U, Li R, Ahmed K, Hart M, Ellis J, Bazett-Jones DP. Open and closed domains in the mouse genome are configured as 10-nm chromatin fibres. EMBO Rep. 2012; 13(11):992-6.

37. Eltsov M, Maclellan KM, Maeshima K, Frangakis AS, Dubochet $J$. Analysis of cryo-electron microscopy images does not support the existence of 30-nm chromatin fibers in mitotic chromosomes in situ. Proc Natl Acad Sci USA. 2008; 105(50):19732-7.

38. Hihara S, Pack CG, Kaizu K, Tani T, Hanafusa T, Nozaki T, Takemoto S, Yoshimi T, Yokota H, Imamoto N, Sako Y, Kinjo M, Takahashi K, Nagai T, Maeshima K. Local nucleosome dynamics facilitate chromatin accessibility in living mammalian cells. Cell Rep. 2012; 2(6):1645-56.

39. Schoenfelder S, Sexton T, Chakalova L, Cope NF, Horton A, Andrews $S$, Kurukuti S, Mitchell JA, Umlauf D, Dimitrova DS, Eskiw CH, Luo Y, Wei CL, Ruan Y, Bieker JJ, Fraser P. Preferential associations between co-regulated genes reveal a transcriptional interactome in erythroid cells. Nat Genet. 2010; 42(1):53-61.

40. Osborne CS, Chakalova L, Brown KE, Carter D, Horton A, Debrand E, Goyenechea B, Mitchell JA, Lopes S, Reik W, Fraser P. 
Active genes dynamically colocalize to shared sites of ongoing transcription. Nat Genet. 2004; 36(10):1065-71.

41. Rapkin LM, Anchel DR, Li R, Bazett-Jones DP. A view of the chromatin landscape. Micron. 2012; 43(2-3):150-8.

42. Gilbert N, Gilchrist $S$, Bickmore WA. Chromatin organization in the mammalian nucleus. Int Rev Cytol. 2005; 242:283-336.

43. Marshall WF. Order and disorder in the nucleus. Curr Biol. 2002; 12(5): 185-92.

44. Marshall WF, Straight A, Marko JF, Swedlow J, Dernburg A, Belmont A, Murray AW, Agard DA, Sedat JW. Interphase chromosomes undergo constrained diffusional motion in living cells. Curr Biol. 1997; 7(12):930-9.

45. Guelen L, Pagie L, Brasset E, Meuleman W, Faza MB, Talhout W, Eussen BH, de Klein A, Wessels L, de Laat W, van Steensel B. Domain organization of human chromosomes revealed by mapping of nuclear lamina interactions. Nature. 2008; 453(7197):948-51.

46. van Bemmel JG, Pagie L, Braunschweig U, Brugman W, Meuleman $W$, Kerkhoven RM, van Steensel B. The insulator protein $\mathrm{SU}(\mathrm{HW})$ fine-tunes nuclear lamina interactions of the Drosophila genome. PLoS One. 2010; 5(11):e15013.

47. van Koningsbruggen S, Gierlinski M, Schofield P, Martin D, Barton GJ, Ariyurek Y, den Dunnen JT, Lamond AI. High-resolution whole-genome sequencing reveals that specific chromatin domains from most human chromosomes associate with nucleoli. Mol Biol Cell. 2010; 21(21):3735-48.

48. Kumaran RI, Spector DL. A genetic locus targeted to the nuclear periphery in living cells maintains its transcriptional competence. J Cell Biol. 2008; 180(1):51-65.

49. Reddy KL, Zullo JM, Bertolino E, Singh H. Transcriptional repression mediated by repositioning of genes to the nuclear lamina. Nature. 2008; 452(7184):243-7.

50. Kind J, Pagie L, Ortabozkoyun H, Boyle S, de Vries SS, Janssen $H$, Amendola $M$, Nolen LD, Bickmore WA, van Steensel B. Single-cell dynamics of genome-nuclear lamina interactions. Cell. 2013; 153(1):178-92.

51. Kind J, van Steensel B. Genome-nuclear lamina interactions and gene regulation. Curr Opin Cell Biol. 2010; 22(3):320-5.

52. Festenstein R, Pagakis $S N$, Hiragami K, Lyon D, Verreault A, Sekkali B, Kioussis D. Modulation of heterochromatin protein 1 dynamics in primary Mammalian cells. Science. 2003; 299(5607): 719-71.

53. Ficz G, Heintzmann R, Arndt-Jovin DJ. Polycomb group protein complexes exchange rapidly in living Drosophila. Development. 2005; 132(17):3963-76.

54. Carter DR, Eskiw C, Cook PR. Transcription factories. Biochem Soc Trans. 2008; 36(Pt 4):585-9.

55. Sutherland H, Bickmore WA. Transcription factories: gene expression in unions? Nat Rev Genet. 2009; 10(7):457-66.

56. Hozak P, Cook PR. Replication factories. Trends Cell Biol. 1994; $4(2): 48-52$

57. Ma H, Samarabandu J, Devdhar RS, Acharya R, Cheng PC, Meng $C$, Berezney $R$. Spatial and temporal dynamics of DNA replication sites in mammalian cells. J Cell Biol. 1998; 143(6): $1415-25$.

58. Adachi Y, Laemmli UK. Identification of nuclear pre-replication centers poised for DNA synthesis in Xenopus egg extracts: immunolocalization study of replication protein A. J Cell Biol. 1992; 119(1):1-15.

59. Berezney R. Visualizing DNA replication sites in the cell nucleus. Semin Cell Biol. 1991; 2(2):103-15.

60. Han J, Herzfeld J. Macromolecular diffusion in crowded solutions. Biophys J. 1993; 65(3):1155-61.
61. Ellis RJ. Macromolecular crowding: obvious but underappreciated. Trends Biochem Sci. 2001; 26(10):597-604.

62. Hancock R. A role for macromolecular crowding effects in the assembly and function of compartments in the nucleus. J Struct Biol. 2004; 146(3):281-90.

63. Razin SV, Gromova II. The channels model of the nuclear matrix structure. Bioessays. 1995; 17(5):443-50.

64. Lebofsky R, Heilig R, Sonnleitner M, Weissenbach J, Bensimon $A$. DNA replication origin interference increases the spacing between initiation events in human cells. Mol Biol Cell. 2006; 17 (12):5337-45.

65. Mechali M, Yoshida K, Coulombe P, Pasero P. Genetic and epigenetic determinants of DNA replication origins, position and activation. Curr Opin Genet Dev. 2013; 23(2):124-31.

66. Jackson DA, Pombo A. Replicon clusters are stable units of chromosome structure: evidence that nuclear organization contributes to the efficient activation and propagation of $\mathrm{S}$ phase in human cells. J Cell Biol. 1998; 140(6):1285-95.

67. Razin SV, Gavrilov AA, Pichugin A, Lipinski M, Iarovaia OV, Vassetzky YS. Transcription factories in the context of the nuclear and genome organization. Nucleic Acids Res. 2011; 39(21):9085-92.

68. Mitchell JA, Fraser P. Transcription factories are nuclear subcompartments that remain in the absence of transcription. Genes Dev. 2008; 22(1):20-5.

69. Marenduzzo D, Finan K, Cook PR. The depletion attraction: an underappreciated force driving cellular organization. $J$ Cell Biol. 2006; 175(5):681-6.

70. Marenduzzo D, Micheletti C, Cook PR. Entropy-driven genome organization. Biophys J. 2006; 90(10):3712-21.

71. Razin SV, Gavrilov AA, Ioudinkova ES, Iarovaia OV. Communication of genome regulatory elements in a folded chromosome. FEBS Lett. 2013; 587(13):1840-7.

72. Cisse II, Izeddin I, Causse SZ, Boudarene L, Senecal A, Muresan L, Dugast-Darzacq C, Hajj B, Dahan M, Darzacq X. Real-time dynamics of RNA polymerase II clustering in live human cells. Science. 2013; 341(6146):664-7.

73. Sims RJ 3rd, Nishioka K, Reinberg D. Histone lysine methylation: a signature for chromatin function. Trends Genet. 2003; 19 (11):629-39.

74. Craig JM. Heterochromatin-many flavours, common themes. Bioessays. 2005; 27(1):17-28.

75. Simon JA, Kingston RE. Occupying chromatin: polycomb mechanisms for getting to genomic targets, stopping transcriptional traffic, and staying put. Mol Cell. 2013; 49(5):808-24.

76. Tiwari VK, McGarvey KM, Licchesi JD, Ohm JE, Herman JG, Schubeler D, Baylin SB. PcG proteins, DNA methylation, and gene repression by chromatin looping. PLoS Biol. 2008; 6(12): 2911-27.

77. Hu Y, Plutz M, Belmont AS. Hsp70 gene association with nuclear speckles is Hsp70 promoter specific. J Cell Biol. 2010; 191 (4):711-9.

78. Huang S, Spector DL. Nascent pre-mRNA transcripts are associated with nuclear regions enriched in splicing factors. Genes Dev. 1991; 5(12A):288-302.

79. Melcak I, Cermanova S, Jirsova K, Koberna K, Malinsky J, Ras$k a I$. Nuclear pre-mRNA compartmentalization: trafficking of released transcripts to splicing factor reservoirs. Mol Biol Cell. 2000; 11(2):497-510.

80. Misteli T. Protein dynamics: implications for nuclear architecture and gene expression. Science. 2001; 291(5505):843-7.

Received 10.01.14 